\title{
NIRA LONTAR SEBAGAI KANDIDAT DALAM MEMPERTAHANKAN KANDUNGAN PROTEIN SILASE JEROAN IKAN CAKALANG
}

\section{(Lontar Sap as Precursor to Retain Protein in Fish Viscera Silage)}

\author{
Yandres Nelson Hege ${ }^{1}$, I Ketut Suwetja ${ }^{2}$, Frans G Ijong ${ }^{2}$ \\ ${ }^{1}$ Program Pascasarjana, Universitas Sam Ratulangi, Manado, Sulawesi Utara. \\ ${ }^{2}$ Fakultas Perikanan dan Ilmu Kelautan Universitas Sam Ratulangi, Manado, Sulawesi Utara.
}

\begin{abstract}
Jeroan ikan sebagai limbah dari pengelolaan ikan cakalang panggang di Kupang, Nusa Tengfgara Timur dapat dimanfaatkan untuk membuat silase dengan menambahkan bahan nira lontar (Borassus flabellifer) yang telah mengalami fermentasi. Fermentasi dilakukan selama $0-15$ hari dan pengujian terhadap total asam, $\mathrm{pH}$, serta kadar protein kasar dilakukan secara teratur. Hasil yang diperoleh menunjukkan bahwa penambáhan nira lontar yang telah difermentasi ke dalam jeroan ikan cakalang pada semua konsentrasi secara nyata memberikan pengaruh terhadap pertumbuhan bakteri asam laktat dan menekan pertumbuhan bakteri petnbusuk, hal ini erat kaitannya dengan kandungan asam (total asam) nira lontar yang berkontribusi terhadap penurunan $\mathrm{pH}$ bahan fermentasi. Produk silase jeroan ikan cakalang terbaik, ditinjau dari aspek kada protein kasar, adalah pada perlakuan konsentrasi nira lontar $10 \%$ dengan lama fermentasi 24 jam yang memiliki kandungan protein sebesar $15,46 \%$ dari berat basah bahan fermentasi (silase).

Kata kunci: Silase, jeroan ikan cakalang, nira lontar, fermentasi

The innards from fresh tuna fish grill in Kupang, Nusa Tenggara Timur can be used to make silage with addition of fermented sap of lontar palm (Borassus flabellifer). Fermentation was carried out for 0-15 days and regularly tested for total acid, $\mathrm{pH}$, as well as the crude protêin content. The results showed that the addition of palm sap that has been fermented into the innards of tuha ay all concentrations significantly impact the growth of lactic acid bacteria and suppress the growth of spoilage bacteria, it is closely related to the acid content (total acid) that contribute to the palm sap decrease in $\mathrm{pH}$ of fermentation ingredients. Tuna offal silage products best viewed from the aspect of the content of crude protein in the treatment of palm sap concentration of $10 \%$ with a 24 -hour fermentation time which has a protein content of $15.46 \%$ by weight of the wet ingredients fermentation (silage)
\end{abstract}

Keywords: Silage, tuna offal, lontařpalm sap, fermentation

PENDAHULUAN

Upaya pemerintah dálam meningkatkan konsumsi ikan secara khusus di Provinsi Nusa Tenggara Timur (NTT) sudah digalakkan semenjak tahun 2001 mela ui berbagai upaya antara lain meningkatkan hasil tangkapan ikan, membangun sarana dan prasărana penjualan ikan bahkan lokasi pengotahan hasil tangkapan. Seiring dengan peningkatân aktivitas tersebut, di sisi lain muncul masalah baru yang berhubungan dengan penanganan limbah sisa hasil olahan ikan seperti jeroan, tulang, insang dan bagian lainnya yang tidak dapat dikonsumsi oleh manusia. Oleh karena itu perlu dilakukan upaya penanggulangan limbah tersebut dalam kerangka meningkatkan nilai tambah sisa buangan hasil olahan dan di sisi lain meminimalisasi polusi terhadap lingkungan terutama bau busuk yang ditimbulkan dari proses pembusukan limbah tersebut oleh bakteri-bakteri pembusuk.
Salah satu upaya yang dapat dilakukan untuk menangani limbah tersebut yaitu melalui proses pembuatan silase yang melibatkan bakteri asam laktat dalam proses fermentasinya, sehingga proses pembusukan oleh bakteri pembusuk selama proses pembuatan silase dapat ditekan pertumbuhannya dan produk silase yang dihasilkan akan memiliki kualitas yang relatif lebih baik. Hasil penelitian Cahyaningsih (2006) menyatakan bahwa nira lontar (Borassus flabellifer) memiliki $\mathrm{pH}$ relatif rendah ( $\mathrm{pH}$ 3-5) dan merupakan sumber bakteri asam laktat (BAL) yang sangat dibutuhkan dalam proses fermentasi silase.

Bakteri asam laktat diketahui mampu menghambat pertumbuhan bakteri pembusuk dan patogen dengan memproduksi senyawa antibakteri. Selain itu kultur BAL juga memiliki aktivitas antimikotik (Jenie et al, 2002; Salminen et al, 2004). 
Berdasarkan uraian tersebut di atas, maka penelitian ini difokuskan pada pemanfaatan nira lontar (Borassus flabellifer) sebagai sumber bakteri asam laktat dalam proses pembuatan silase dengan memanfaatkan limbah hasil olahan ikan sebagai bahan bukunya.

\section{METODE PENELITIAN}

\section{Bahan dan alat}

Bahan baku yang digunakan adalah limbah jeroan ikan cakalang yang diperoleh dari tempat pengolahan ikan di Kelurahan Pasir Panjang, Kota Kupang, NTT. Sedangkan nira lontar diperoleh dari petani selanjutnya difermentasi selama 12 dan 24 jam untuk digunakan sebagai sumber bakteri asam laktat. Peralatan yang digunakan untuk wadah fermentasi berupa toples kaca yang dilengkapi dengan tutup dan untuk proses fermentasinya ditempatkan dalam sebuah inkubator yang dirancang menggunakan kotak gabus sintetis berdimensi $49 \times 39 \times 32 \mathrm{~cm}$, dan pada tutupnya dipasang 2 buah lampu pijar 5 watt yang berfungsi sebagai sumber panas untuk menghasilkan suhu ruang fermentasi antara $35-45^{\circ} \mathrm{C}$ (Gambar 1).

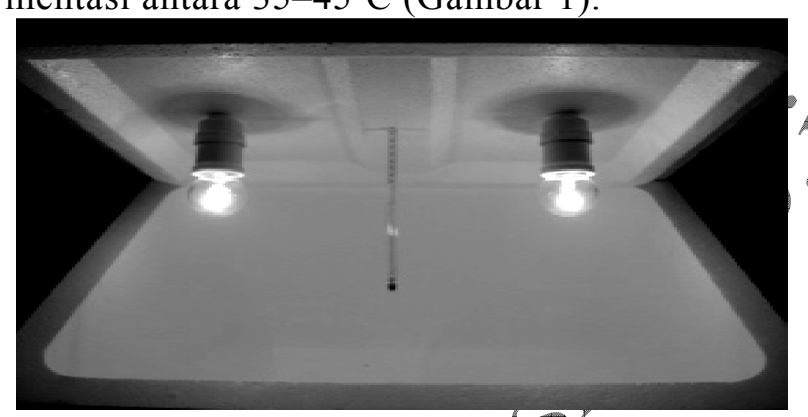

Gambar 1. Fermentor.

\section{Prose pembuatan silase}

Sejumlah $10 \mathrm{Kg}$ jeroan ikan cakalang yang telah didinginkan dengan es selama proses transportasi, dibersihkan menggunakan air mengalir kemudian dihaluskan, ditimbang sejumlah $500 \mathrm{~g}$ per wadah dan dicampur nira lontar hasil fermentasi masing-masing untuk 12 jam fermentasi mengandung yotal koloni BAL 3,9x104 CFU/g dan untuk 24 jam mengandung total koloni BAL 3,3 x104 CEU/g (Hege, 2012) dengan konsentrasi 5\%, $10 \%$ dan $15 \%$ dari berat bahan baku, selanjutnya semua wadah fermentasi dimasukkan dalam inkubator dan difermentasi selama 15 hari. Prosedur pembuatan silase jeroan ikan cakalang seperti ditunjukkan pada Gambar 2.

\section{Analisa kimiawi}

Analisa kimiawi dilakukan pada beberapa waktu fermentasi yaitu 0, 5, 10 dan 15 hari, meli- puti pengukuran $\mathrm{pH}$ dan Total Asam menurut metode Nout et al. (1989) yang dimodifikasi oleh Ijong dan Ohta (1996), sedangkan analisa kadar protein kasar dilakukan dengan metode Kjeldahl (Sudarmadji, et al., 1989). Semua data yang diperoleh dari hasil analisa laboratorium selanjutnya dihitung menggunakan Anova yang diintegrasikan dengan uji Duncan (Gasperz, 1994).
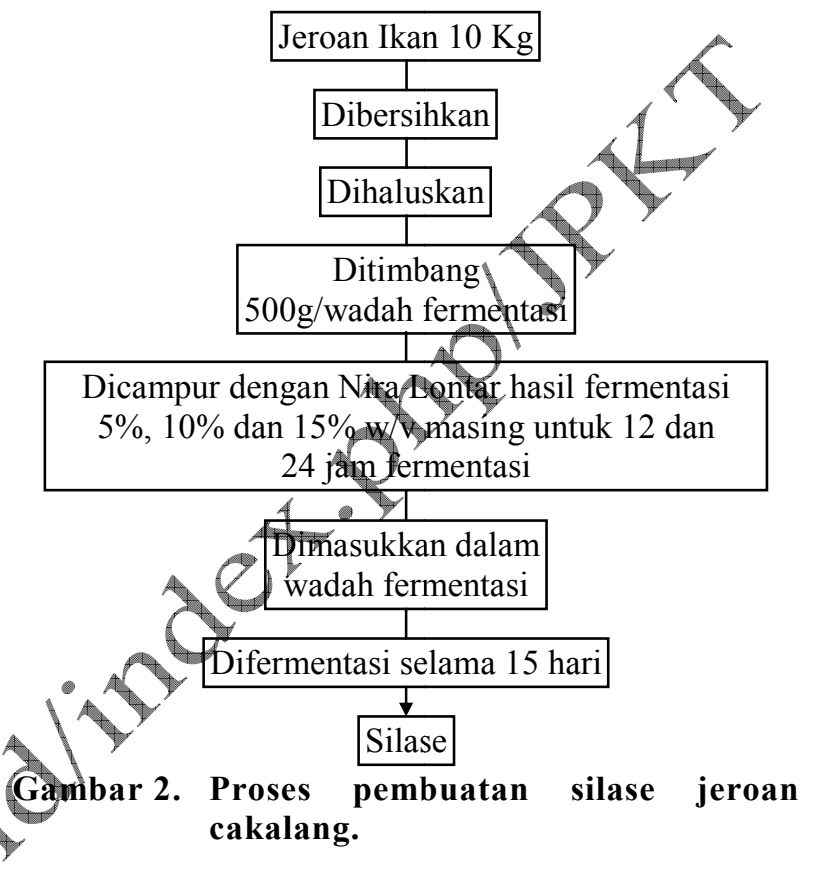

\section{HASIL DAN PEMBAHASAN}

Hasil pengamatan pada hari fermentasi ke 15 terhadap aspek sensori umum semua sampel silase yang dibuat dengan penambahan nira lontar yang telah difermentasi baik untuk 12 jam maupun 24 jam menunjukkan bahwa produk silase yang dihasilkan menunjukkan penampakkan berwarna kecoklatan dengan tekstur agak kental dengan bau khas. Hasil penelitian ini menunjukkan bahwa penambahan nira lontar yang telah difermentasi baik untuk 12 jam maupun 24 jam ke dalam jeroan ikan cakalang pada semua konsentrasi $(5 \%, 10 \%$ dan $15 \%)$ secara nyata memberikan pengaruh terhadap pertumbuhan bakteri asam laktat dan menekan pertumbuhan bakteri pembusuk, hal ini erat kaitannya dengan kandungan asam (total asam) nira lontar yang berkontribusi terhadap penurunan $\mathrm{pH}$ bahan fermentasi seperti diuraikan pada Tabel 1.

Tabel 1. Nilai total asam dan pH nira lontar hasil fermentasi.

\begin{tabular}{ccc}
\hline Lama Fermentasi & Total Asam (\%,v/v) & pH \\
\hline 24 & 1,56 & 4,98 \\
48 & 1,02 & 4,23 \\
\hline
\end{tabular}


Hasil ini sejalan dengan yang dilaporkan oleh Ijong (1996) terhadap produk fermentasi bakasang, bahwa fermentasi oleh bakteri asam laktat mengakibatkan meningkatnya total asam yang berpengaruh terhadap rendahnya $\mathrm{pH}$ bahan fermentasi menjadi sekitar $\mathrm{pH}$ 4,84 sehingga berpotensi menekan pertumbuhan bakteri pembusuk di satu sisi dan di sisi lainnya membantu terciptanya suasana yang ideal bagi pertumbuhan bakteri asam laktat.

Gambar 3 menunjukkan total kandungan protein kasar silase jeroan cakalang difermentasi dengan nira lontar pada beberapa perlakukan yang diberikan. Kadar protein kasar tertinggi diperoleh pada perlakukan konsentrasi nira $10 \%$ dengan lama fermentasi 24 jam sebesar $15,46 \%$ pada penyimpanan hari ke-10, sedangkan kadar protein kasar terendah diperoleh pada perlakukan penambahan nira lontar 5\% dengan lama fermentasi 12 jam sebesar $10,30 \%$, dimana masing-masing nilai protein kasar ini jika dikoversi berdasarkan berat kering maka kadar protein kasar silase jeroan ikan cakalang akan berkisar antara 39,7-49,9\%. Bervariasinya kadar protein kasar pada setiap perlakukan sangat dipengaruhi oleh komposisi proksimat bahan baku yang digunakan, terutama pada kandungan air bahan fermentasi (Ijong dan Ohta, 1995, 1996). Secara statistik diperoleh bahwa hasil penelitian dengan penambahan nira lontar 5\% sampai $15 \%$ yang telah difermentasi baik 12 jam maupun 24 jam, tidak menunjukkan perbedaan yang sangat nyata terhadap peningkatan kadaf protein kasar, kecuali faktor lama fermentasi memberikan pengaruh nyata $(\mathrm{p}<0,01)$ terhadap peningkatan kadar protein kasar silase jeroan ikan cakalang. Ijong dan Ohta (1995) menyatakan bahwa laju hidrolisa pada bakasang sardin yang di fer- mentasi dengan penambahan bakteri asam laktat sangat berpengaruh terhadap kandungan air bahan fermentasi, sehingga produk yang dihasilkan cenderung memiliki kadar tinggi $(66,86-71,86 \%)$. Produk silase jeroan cakalang yang difermentasi dengan penambahan nira lontar memiliki kisaran kadar air antara 64,60-68,78\% (Hege, 2012). Hasil penelitian ini memberi gambaran bahwa nira lontar yang difermentasi memiliki kandungan bakteri asam laktat yang potensil untuk meningkatkan nilai nutrisi terutama kandungan protein terlarut pada silase jeroan ikan cakalang, walaupun niłai protein kasar silase jeroan ikan cakalang masih agak rendah dibandingkan dengan hasil penelitian yang dilaporkan oleh Utama dan Sumarsity (2010) yang menyatakan bahwa penambahan elkstrak kubis antara $12-17,5 \%$ pada pembuatan silase ikan tidak memberikan pengaruh nyata terhadap peningkatan kadar protein kasar, sekalipun kandungan protein kasar yang dihasilkan pada silase ikan relatif jauh lebih tinggi (berkisar $53,69-55,32 \%$ ) dari kandungan protein pada ikan segar.

\section{KESIMPULAN}

Y Nira lontar yang difermentasi berpotensi sebdgai sumber bakteri asam laktat pada pembuatan silase jeroan cakalang yang berperan dalam proses fermentasi. Produk silase jeroan ikan cakalang terbaik dalam penelitian ini ditinjau dari aspek kadar protein kasar yaitu pada perlakuan konsentrasi nira 10\% dengan lama fermentasi 24 jam yang memiliki kandungan sebesar $15,46 \%$ jika dihitung berdasarkan berat basah atau $49,9 \%$ jika di hitung berdasarkan berat keringnya.

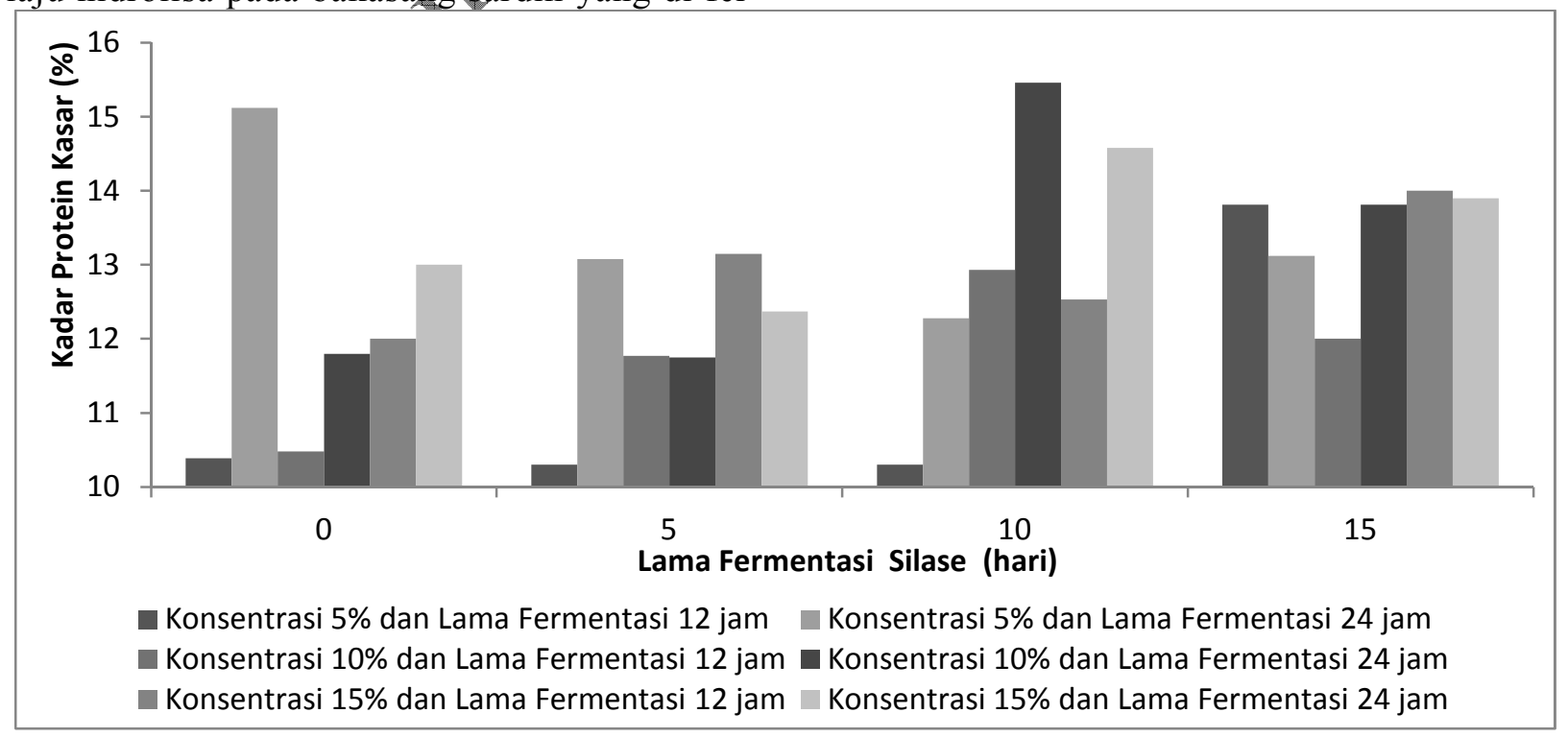

Gambar 3. Histogram interaksi antara perlakuan konsentrasi nira, lama fermentasi terhadap rerata kadar protein kasar (\%) silase jeroan ikan cakalang. 


\section{UCAPAN TERIMA KASIH}

Pada kesempatan ini kami ucapan terima kasih kepada NPT-250 Nuffic Agriculture Kerja sama NUFFIC Belanda MDF-Pacific Indonesia dengan Politeknik Pertanian Negeri Kupang.

\section{DAFTAR PUSTAKA}

Cahyaningsih, E. 2006. Identifikasi BAL Nira Lontar yang Memiliki Aktivitas Antimikroba dan Aplikasinya sebagai Pengawet Hayati Biji Coklat. Thesis. Pascasarjana-IPB. Bogor.

Gasperz V. 1994. Teknis Analisis Dalam Penelitian Percobaan. Tarsito Bandung.

Ijong FG and Y Ohta. 1995. Characteristic of Bakasang Fermented with Lactic Acid Bacteria-Mixed Culture. Faculty of Applied Biological Science, Hiroshima University. Hiroshima-Japan.
Ijong, FG and Y Ohta. 1996. Psychochemical And Microbiological Changer Associated With Bakasang Processing- A. Traditional Indonesian Fermented Fish Sauce. Laboratory Of Microbial Biochemistry. J Science of Food and Agriculture. 71, 69-74.

Ijong FG. 1996. Study Of Bakasang Traditional Fish Sauce From Indonesian. Doctoral Thesis. Hiroshima University, Japan 156 hal.

Utama CS dan S Sumarsih. 2010. Pengaruh Penambahan Aras Ekstrak Kubis Sortir dan Lama Pemeraman Terhadap Kandungan Nutrisi Silase Ikan. Jurnal Ilmu Kesehatan Vol. 3 No.1 (http://jurnal.unimus.ac.id, 15.45, 24/4/2013)

Hege YN. 2012. Pembuatan Silase dari Limbah Jeroan Ikan Cakalang (Katsuwonus palamis, L) yang Pifermentasi dengan Nira Lontar (Borassus flabellifen-L). Tesis Magister Sains, Pascasarjana Universitas Sam Ratulangi, Manado. 92 hal.

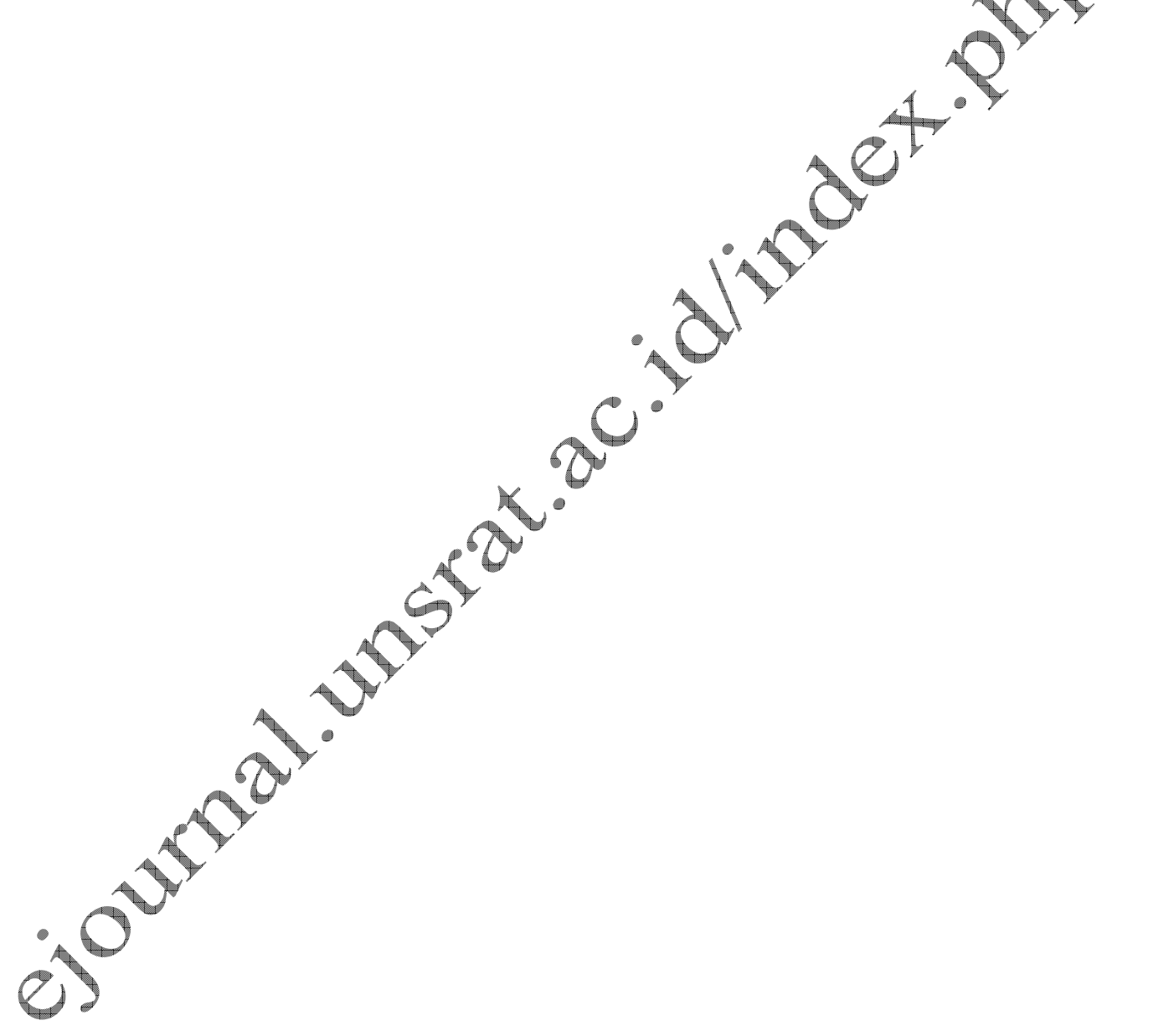

